\title{
Fueling the Flames: Mammalian Programmed Necrosis in Inflammatory Diseases
}

\author{
Francis Ka-Ming Chan \\ Department of Pathology, Immunology and Virology Program, University of Massachusetts Medical School, \\ Worcester, Massachusetts 01655 \\ Correspondence: francis.chan@umassmed.edu
}

\begin{abstract}
Programmed necrosis or necroptosis is an inflammatory form of cell death driven by TNF-like death cytokines, toll-like receptors, and antigen receptors. Unlike necrosis induced by physical trauma, a dedicated pathway is involved in programmed necrosis. In particular, a kinase complex composed of the receptor interacting protein kinase 1 (RIPK1) and RIPK3 is a central step in necrotic cell death. Assembly and activation of this RIPK1-RIPK3 "necrosome" is critically controlled by protein ubiquitination, phosphorylation, and caspase-mediated cleavage events. The molecular signals cumulate in formation of intracellular vacuoles, organelle swelling, internal membrane leakage, and eventually plasma membrane rupture. These morphological changes can result in spillage of intracellular adjuvants to promote inflammation and further exacerbate tissue injury. Because of the inflammatory nature of necrosis, it is an attractive pathway for therapeutic intervention in acute inflammatory diseases.
\end{abstract}

$\mathrm{N}_{\mathrm{t} \text { e }}^{\mathrm{e}}$ ecrosis and tissue inflammation are two tightly linked phenomena. Cell injury induced by excessive trauma such as heat shock and osmotic shock can result in cell death with "necrotic morphology." These relatively nonspecific means to trigger necrosis have contributed to the notion that necrosis is caused by excessive insults and does not involve elaborate intracellular signaling pathways. In contrast to the notion that necrosis is associated with harmful pathologies, recent work indicates that necrosis can have beneficial roles in certain biological responses. Proteomic approaches and RNA interference screens have identified several crucial regulators of necrosis induced by TNF-like death cytokines. Because a dedicated molecular circuitry is involved, the terms "programmed ne- crosis" and "necroptosis" have been used to distinguish these types of necrotic cell death from necrosis induced by physical trauma or insults. Here I will discuss the molecular pathway that regulates programmed necrosis/necroptosis. For the sake of simplicity, we will use the term necrosis to refer to programmed necrosis induced by defined death cytokines.

\section{MORPHOLOGICAL FEATURES OF NECROSIS}

Similar to apoptosis, necrosis is best defined by its characteristic morphologies. Necrotic cells are typically marked by organelle and cell swelling, and plasma membrane leakage. These features resemble "oncosis" (Majno and Joris

Editors: Eric H. Baehrecke, Douglas R. Green, Sally Kornbluth, and Guy S. Salvesen

Additional Perspectives on Cell Survival and Cell Death available at www.cshperspectives.org

Copyright (C) 2012 Cold Spring Harbor Laboratory Press; all rights reserved; doi: 10.1101/cshperspect.a008805

Cite this article as Cold Spring Harb Perspect Biol 2012;4:a008805 
F.K.-M. Chan

1995), a term that was used to describe cell death with organelle and cell swelling more than one hundred years ago by the German pathologist F. von Recklinghausen (von Recklinghausen 1910). By electron microscopy, numerous small vacuoles can be seen in early necrotic cells (Fig. 1A). The small vacuoles appear to swell or coalesce with each other to form larger vacuoles (Fig. 1B). The identity of these vacuoles is currently unknown, but may be the result of swelling of ER membranes or lysosomes (Vanden Berghe et al. 2010). In addition to the vacuoles, mitochondrial distension can be readily detected (Fig. 1A). Whether these intracellular changes are the cause or consequence of necrosis signaling awaits further experimental evidence. It is noteworthy that the larger vacuoles often show some lesions on their membranes (Fig. 1B). These intracellular membrane lesions can be detected in cells with intact plasma membranes. Thus, internal membrane damage precedes plasma membrane leakage in necrosis. Based on these morphological changes, I can consider necrosis as cell death through "internal bleeding."

\section{CROSSTALK BETWEEN NECROSIS AND OTHER CELL DEATH PATHWAYS}

In the laboratory, caspase inhibitors are often used to optimally induce necrosis. Because caspases are key initiators and effectors for apoptosis, the requirement for caspase inhibition for necrosis suggests that molecular crosstalk between the two cell death pathways exists. In addition to priming cells to necrosis, caspase inhibition can activate autophagy in some situations (Yu et al. 2004). Although autophagy is predominantly a survival response to stress signals, it can cause cell death under certain conditions, such as that during development of the salivary gland in Drosophila (Berry and Baehrecke 2007). One of the functions of autophagy is to remove damaged proteins and organelles, such as that found in necrotic cells. Leakage of damaged proteins from necrotic cells can elicit a proinflammatory response in the tissue milieu, resulting in further damage from infiltrating immune effector cells. As such, when death receptors are turned on in the presence caspase inhibition, autophagy may represent a
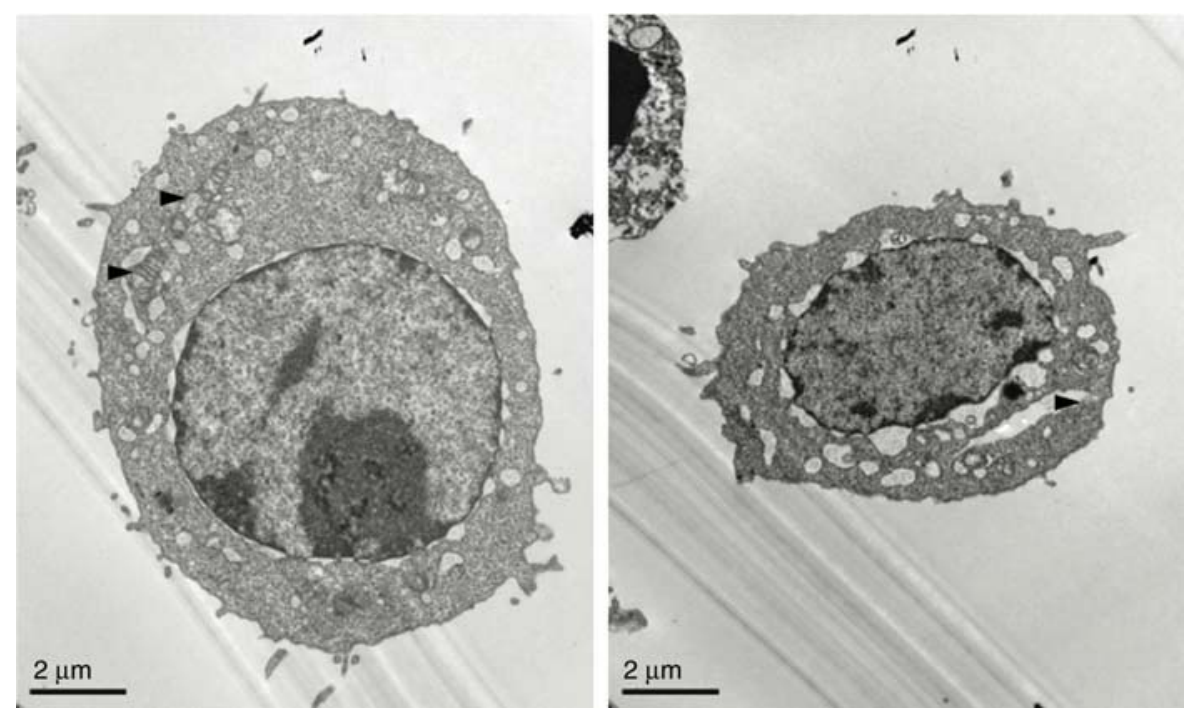

Figure 1. Programmed necrosis is marked by extensive organelle and cell swelling. ( $A$ ) Formation of intracellular vacuoles and swelling of mitochondria in $\mathrm{FADD}^{-/-} \mathrm{T}$ cells stimulated with plate-bound anti-CD3 (T-cell receptor) antibody. The arrows show the swelling of mitochondria. (B) Membrane rupture of large intracellular vacuoles in anti-CD3 activated $\mathrm{FADD}^{-/-} \mathrm{T}$ cells. The arrow highlights the region of membrane leakage. Note that the plasma membrane is still intact. 
last resort for cells to avoid the damaging effects of necrosis. In this scenario, apoptosis, autophagy, and necrosis may represent a continuum of cell death modules with increasing propensity to drives inflammation. It implies that the pathways that regulate these different cell death programs are intimately linked. This progression of cell death modules is an important mechanism for multicellular organisms to control and limit the deleterious consequences of cell death.

We now know that many cell surface receptors can induce cellular necrosis. These include cytokines in the TNF superfamily, toll-like receptors (He et al. 2011; McComb et al. 2012), Tcell receptor (Ch'en et al. 2008; Cho et al. 2011; Zhang et al. 2011), DNA alkylating agents (Tu et al. 2009), and certain cytotoxic drugs (He et al. 2009; Zhang et al. 2009). These upstream triggers use a core pathway to induce necrosis that involves the receptor interacting protein kinase 3 (RIPK3). Depending on the upstream activator, RIPK3 can engage different binding partners to induce necrosis. Because the pathway mediated by TNF-TNF receptor ligation is the best characterized, I will use it to illustrate certain core principles.

\section{NECROSIS IS TIGHTLY REGULATED BY RIPK1 UBIQUITINATION}

TNF is a pleiotropic cytokine that triggers diverse biological responses including de novo gene expression and cell death by apoptosis or necrosis. As its name implies (tumor necrosis factor), TNF was made famous because it could induce necrosis in solid tumors (Carswell et al. 1975). The strong proinflammatory effects of TNF, however, preclude its use in the clinic. The receptor interacting protein kinase 1 (RIPK1) is a key regulator of the switch between NF- $\kappa \mathrm{B}$ activation and cell death induction by TNF. RIPK1 is a serine/threonine kinase that contains a death domain at the carboxyl terminus. It was originally identified in a yeast two-hybrid screen as an interacting partner to the death domain of Fas/ CD95/APO-1 and thus was thought to be a crucial adaptor that mediates Fas-induced apoptosis (Stanger et al. 1995). However, it was not until recently that RIPK1 was shown to be part of the signaling complex that mediates Fas-induced apoptosis (Geserick et al. 2009), especially that through membrane-anchored FasL (Morgan et al. 2009). In contrast to the early connotation that RIPK1 is a death inducer, Goeddel and Ting showed that RIPK1 is recruited to the TNF receptor 1 (TNFR-1) and has an important role in activation of the prosurvival transcription factor NF-кB (Hsu et al. 1996; Ting et al. 1996). Accordingly, RIPK1 $1^{-/-}$cells are defective for TNF-induced NF- $\kappa$ B activation (Kelliher et al. 1998), although this early finding has recently been challenged (Wong et al. 2010). Nonetheless, it is clear that RIPK1, especially when it is polyubiquitinated, has a prosurvival function.

RIPK1 ubiquitination occurs when it is recruited to the membrane-associated TNFR1 ( p55/p60) complex, termed "Complex I" by Micheau and Tschopp (Micheau and Tschopp 2003). The E3 ligases, cIAP-1 and cIAP-2, are responsible for RIPK1 polyubiquitination. Several reports indicate that K63 ubiquitination at Lys 377 of RIPK1 is essential for recruitment of NEMO and activation of the IKK complex (Ea et al. 2006; Li et al. 2006). However, recent studies using proteomic approaches (Mollah et al. 2007), linkage-specific ubiquitin antibodies (Newton et al. 2008), and ubiquitin replacement strategy (Xu et al. 2009) clearly show that ubiquitination at sites other than K377 as well as other types of ubiquitin linkage can also occur. Polyubiquitinated RIPK1 can promote cell survival through NF- $\kappa \mathrm{B}$ activation by recruiting downstream factors such as NEMO and the IKK complex. In addition, it can serve as a gatekeeper to prevent assembly of the death-inducing cytoplasmic "Complex II" as the membrane bound Complex I become internalized (O'Donnell et al. 2007). This explains why Smac mimetics or IAP antagonists, which target cIAP-1, cIAP-2, and XIAP for autoubiquitination and degradation to promote assembly of the ripoptosome (Petersen et al. 2007; Varfolomeev et al. 2007; Vince et al. 2007; Bertrand et al. 2008), can further enhance TNFinduced necrosis. It also is consistent with the fact that siRNA knock-down of the RIPK1 deubiquitinase cylindromatosis (CYLD) can protect cells 
F.K.-M. Chan

against necrosis (O’Donnell et al. 2007; Hitomi et al. 2008; Vanlangenakker et al. 2011). Although it has yet to be proven experimentally, it is tempting to speculate that polyubiquitin chains on RIPK1 may sterically prevent binding of downstream necrosis mediators.

\section{CASPASE 8 INHIBITS NECROSIS BY TARGETING ESSENTIAL NECROSOME COMPONENTS}

Besides necrosis, blocking RIPK1 polyubiquitination has a similar enhancing effect to apoptosis. This indicates that additional signals are required to discriminate between the two death inducing responses. From the early days, it is clear that tetra-peptide caspase inhibitors or viral caspase inhibitors can greatly enhance cellular necrosis (Vercammen et al. 1998). The molecular basis for this requirement lies in part to the fact that necrosis mediators such as RIPK1, RIPK3, and CYLD are substrates of caspase 8 (Lin et al. 1999; Chan et al. 2003; Feng et al. 2007; O'Donnell et al. 2011). In the case of RIPK1, cleavage of RIPK1 at D324 separates the amino terminal kinase domain from the carboxyl terminus that contains the death domain and the RIP homotypic interaction motif
(RHIM) (see below). Therefore, caspase 8 cleavage will prevent RIPK1 from phosphorylating its downstream substrate RIPK3 (Fig. 2).

\section{RIPK3: THE MASTERMIND OF NECROSIS}

In addition to promoting necrosis, the kinase function of RIPK1 is also required for ripoptosome assembly, caspase 8 activation and apoptosis induced by TNF and Smac mimetic (Wang et al. 2008; Feoktistova et al. 2011; Tenev et al. 2011). Because RIPK3 is not activated unless caspase 8 is inhibited, distinct RIPK1 substrates are involved in TNF and Smac mimetic induced apoptosis. RIPK3 was identified in several RNA interference screens to be a critical partner of RIPK1 in necrosis (Cho et al. 2009; He et al. 2009). Both RIPK1 and RIPK3 are phosphorylated during necrosis, perhaps through transphosphorylation. They formed a tight and stable complex termed the "necrosome" (Vandenabeele et al. 2010). As discussed in the previous section, formation of the necrosome requires caspase inhibition (Cho et al. 2009; He et al. 2009; Zhang et al. 2009), because RIPK1 and RIPK3 are both substrates of caspase 8 (Lin et al. 1999; Feng et al. 2007).

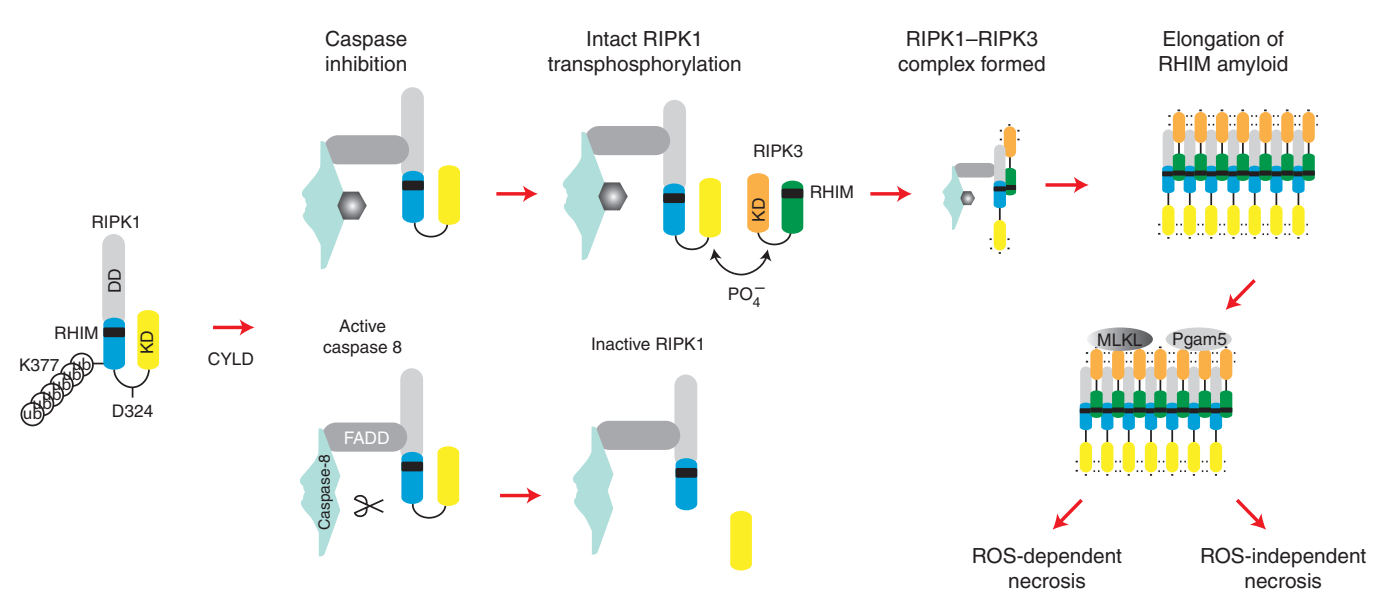

Figure 2. Schematic diagram highlighting the major regulatory steps in the necrosis pathway. De-ubiquitination of RIPK1 by CYLD facilitates assembly of the FADD-caspase 8-RIPK1 ripoptosome. Inhibition of caspase 8 allows RIPK1-RIPK3 necrosome assembly. The negative charge that results from transphosphorylation of RIPK1 and RIPK3 in the kinase domains relieves the inhibition on the RHIM, thereby promoting the amyloidal scaffold to form. This then allows recruitment of downstream RIPK3 substrates including MLKL and Pgam5. 
Assembly of the RIPK1-RIPK3 necrosome also requires an intact RHIM. The RHIM is an emerging protein-protein interaction domain found in several other adaptors with functions in innate immune and cell death signaling (Fig. 3). Unlike many other protein-protein interaction motifs, the RHIM homology is illdefined with only a core of mostly hydrophobic residues that are highly conserved among different RHIMs (Fig. 3). In the case of RIPK1 and RIPK3, the core RHIM tetra-peptide (I/ $\mathrm{V}) \mathrm{Q}(\mathrm{I} / \mathrm{V}) \mathrm{G}$ and its flanking residues are predicted $\beta$-sheet structures. Interestingly, recombinant RIPK1 and RIPK3 fragments containing the RHIM assemble in a 1:1 ratio to form large filamentous fibrils. Biophysical studies show that the RHIM core and its flanking sequences behave as amyloid-like fibrils ( $\mathrm{Li}$ et al. 2012). Mutagenesis of the RHIM core sequences show that this amyloidal assembly is crucial for activation of RIPK1 and RIPK3 kinase activity, necrosome clusters formation, and necrosis induction ( $\mathrm{Li}$ et al. 2012) (Fig. 2). Intriguingly, truncated RIPK1 and RIPK3 lacking the kinase domains, but not full-length RIP kinases, spontaneously assemble into amyloid-like fibrils. The kinase domains may "mask" the RHIM to prevent amyloid complex formation before activation. Upon phosphorylation of residues in the kinase domains, the RHIM may become unmasked because of negative charge repulsion to allow the RHIM amyloid structures to form (Fig. 2). Because mutations in the RHIM also affect kinase activity, kinase activation and amyloid assembly may be mutually reinforcing reactions. Consistent with this model, both RIPK1 and RIPK3 are phosphorylated at multiple sites in the kinase domains (Degterev et al. 2008; He et al. 2009; Sun et al. 2012).
As I alluded to earlier, RIPK3 can partner with other RHIM-containing adaptors to trigger necrosis. For example, TLR3 and TLR4 induced macrophage necrosis requires the action of RIPK3 and TRIF (He et al. 2011). The viral necrosis inhibitor M45 prevents RIPK3-DAI (DNA activator of interferon) induced necrosis during MCMV infection to inhibit premature host cell death before completion of viral replication (Upton et al. 2008, 2010). Formation of these noncanonical necrosomes also requires RHIM-RHIM interactions. At present, it is unclear if similar amyloidal structures are involved in assembly of these noncanonical necrosomes. However, it is noteworthy that RHIM-RHIM interaction between RIPK1, RIPK3, and TRIF is also required for TLR3 and TLR4 induced NF- $\kappa$ B activation (Meylan et al. 2004; Kaiser et al. 2008; Rebsamen et al. 2009). This raises the interesting and important question of whether the amyloidal assembly of RHIM-containing complexes is strictly involved in necrosis signaling. Because transmission of the necrotic signal requires recruitment of downstream RIPK3 substrates to the necrosome, it seems reasonable to speculate that RHIM-containing amyloid complexes can signal for necrosis and NF$\kappa \mathrm{B}$ in a context dependent manner. This is unlike in neurodegenerative diseases in which amyloid complexes appear to be directly responsible for cell injury.

\section{TRACKING THE ELUSIVE KILLER- DOWNSTREAM EVENTS IN NECROSIS}

The mixed lineage kinase domain-like (MLKL) was identified as a kinase substrate of RIPK3 using biochemical purification and RNA interference screen (Sun et al. 2012; Zhao et al. 2012).
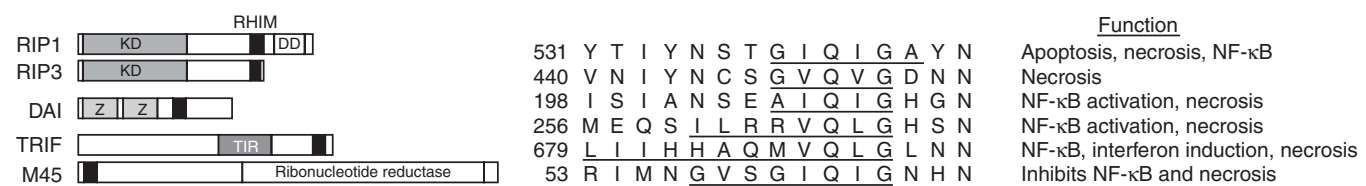

Figure 3. RHIM-containing proteins are critical regulators of cell death and innate immune signaling. (Left) Schematic diagram of protein adaptors with RHIM. KD, kinase domain; DD, death domain; Z, Z-DNA-binding domain; TIR, Toll/IL-1R domain. The black boxes denote the RHIM. (Middle) Sequence alignment of core RHIM sequences from different adaptors. Predicted $\beta$ sheet is underlined using the Robson-Garnier method. 
F.K.-M. Chan

MLKL has a kinase domain in the carboxyl terminus and an amino terminal coil-coil domain. RIPK3 binds to and phosphorylate the kinase domain of MLKL. Although the name implies that MLKL is a pseudokinase, Liu and colleagues show that mutations of the conserved active site abolished the necrosis inducing function of MLKL (Zhao et al. 2012). Therefore, MLKL may function as the third kinase in the cascade. The significance of MLKL is further revealed through identification of a necrosis inhibitor termed "necrosulfonamide" (NSA) through a small molecule library screen. NSA inhibits necrosis by covalently modifying cysteine 86 that is uniquely present in human MLKL, but not in mouse MLKL (Sun et al. 2012). Thus, unlike necrostatin- 1 and its derivatives (Degterev et al. 2005), which target and inhibit RIPK1 kinase activity in both human and mouse cells (Degterev et al. 2008), NSA is a human cell specific inhibitor of necrosis.

Unlike necrostatin-1, NSA did not interfere with RIPK1-RIPK3 necrosome formation. Instead, NSA blocks recruitment of phosphoglycerate mutase family member 5 short (Pgam5s) to the necrosome. Similar to MLKL, both isoforms of Pgam5 Pgam5s and Pgam5L, were identified through biochemical purification as RIPK3 substrates and binding partners (Wang et al. 2012). Pgam5 functions as a phosphatase, not a mutase, as its name might imply (Takeda et al. 2009). Overexpression of Pgam5 causes mitochondrial fragmentation (Lo and Hannink 2008), a phenomenon observed in some necrotic cells. Because inhibition with NSA prevented the recruitment of Pgam5s to RIPK3, MLKL appears to function as a key adaptor that links the RIPK1-RIPK3 necrosome to downstream effectors. Pgam5s has a strong propensity to localize to the mitochondria, suggesting that Pgam5 might tether the RIPK1-RIPK3 necrosome to induce mitochondria fragmentation. Pgam 5 dephosphorylates and activates the mitochondria fission factor Drp-1 (Wang et al. 2012), raising the interesting possibility that the necrosome can engage the mitochondria fission machinery to execute necrosis.

The discovery of Pgam5 suggests that similar to apoptosis, the mitochondria may be in- volved in necrosis signaling. One widely popular view is that reactive oxygen species (ROS) produced by damaged mitochondria may be critical mediators for the execution of necrosis. However, in many cells such as lymphocytes, ROS scavengers do not protect against TNF-induced necrosis ( $\mathrm{T}$ McQuade and FK-M Chan, unpubl.). This suggests that Pgam5 and other factors that can potentially promote mitochondrial ROS generation may not be universally required for necrosis in all cell types.

Although ROS is not required for necrosis in lymphocytes, ROS scavengers are effective inhibitors of necrosis in many cell types. There are two major sources of cellular ROS: those generated at the mitochondria as a result of oxidative phosphorylation, and those that are generated by membrane associated NADPH oxidases (NOX). Evidence that support a role for both sources of ROS in necrosis can be found (Goossens et al. 1999). Some reports suggest that direct activation of plasma membrane associated NADPH oxidases is a major source of ROS in necrotic cells (Kim et al. 2007; Yazdanpanah et al. 2009). In contrast, ROS production was abrogated in cells lacking essential necrosome components such as RIPK3 and MLKL (Cho et al. 2009; Sun et al. 2012). Because the necrosome is formed in the cytosol subsequent to dissolution of the membrane signaling complex, it argues against a role for the plasma membrane associated NOX in ROS generation. Paradoxically, necrosis induced by hydrogen peroxide, which generates ROS once it enters the cell, is impaired in the absence of Pgam5 (Wang et al. 2012). These results suggest that besides being a product of necrosome activation, ROS may function in a feed-forward manner to promote necrosome function. It is clear that more work is needed to determine the precise source and role of ROS in necrosis.

\section{NECROSIS IN PATHOGEN-INDUCED INFLAMMATION}

It is well known to pathologists that necrosis is often associated with inflammation. As discussed in previous sections, protein adaptors that contain RHIM domains share functions 
in cell death and/or innate immune signaling. This molecular signature suggests that the RIP kinases and necrosis have broad roles in innate immunity and inflammation. The first example that highlights this paradigm comes from study of host defense against vaccinia virus infection. Vaccinia virus, like other poxviruses, encodes many immune evasion genes. One of these gene products, B13R or Spi2, is a serpin that inhibits caspase 1 and caspase 8 , and is similar functionally to CrmA from cowpox virus (Zhou et al. 1997). Despite the inhibition of caspase 8, vaccinia virus infected cells are still sensitive to the cytotoxic effect of TNF ( $\mathrm{Li}$ and Beg 2000). TNF-induced cell death of vaccinia virus infected cells show morphology that resembles necrosis and requires intact RIPK1 and RIPK3 functions (Chan et al. 2003; Cho et al. 2009). Consistent with these in vitro infection results, RIPK $^{-/-}$mice show reduced necrosis and inflammation, greatly increased viral replication, and succumb to virus $4-5 \mathrm{~d}$ postinfection (Cho et al. 2009). Thus, in poxvirus infection, host cell necrosis during the innate phase of the immune reaction limits the viral factory. This is crucial for host survival before virus-specific $\mathrm{T}$ and $\mathrm{B}$ lymphocytes are mobilized in high enough number to control the virus.

The sensitization of vaccinia virus infected cells to TNF-induced necrosis is reminiscent of the effect of peptide-based caspase inhibitors. This suggests that other viruses that encode caspase inhibitors may similarly prime cells to necrosis. Murine cytomegalovirus (MCMV) encodes three different types of viral cell death inhibitors, vICA (inhibitor of caspase 8-induced apoptosis), vMIA (mitochondria inhibitor of apoptosis) and vIRA (inhibitor of RIP activation) (reviewed in Mocarski et al. 2012). Productive infection and replication of viral progenies require the action of all three inhibitors. vIRA or M45 encodes a protein with homology to ribonucleotide reductase (Brune et al. 2001). However, it has no enzymatic activity (Lembo et al. 2004). Rather, the RHIM domain within M45 is crucial for binding to cellular factors that also contain RHIM domains, including RIPK1, RIPK3, and DAI (Kaiser et al. 2008; Upton et al. 2008, 2012; Rebsamen et al.
2009). Recombinant virus that encodes a defective vIRA with tetra-alanine substitutions of the RHIM fails to establish productive infection in cells and in mice because of premature cell death by necrosis. Significantly, productive infection is restored when the RHIM mutant MCMV infects RIPK3 ${ }^{-/-}$mice (Upton et al. 2010). The necrotic cell death induced on mutant MCMV infection is not driven by TNF or RIPK1. Instead, RIPK3 pairs with another RHIM-containing adaptor DAI to induce necrosis in the absence of a functional M45/vIRA (Upton et al. 2012). Similar to poxviruses, necrosis is a defense mechanism of the host against MCMV. However, in contrast to vaccinia virus, MCMV has developed an effective strategy to circumvent host cell necrosis.

The MCMV results tell us that active suppression of host cell necrosis is an important survival mechanism of the virus. This suggests that other viruses may also encode necrosis inhibitors. Viral FLIPs are orthologs of cellular caspase 8/10 that contain tandem death effector domains, but lack the enzymatic domains. They were identified first as caspase and apoptosis inhibitors (Bertin et al. 1997; Hu et al. 1997; Thome et al. 1997). A subset of vFLIPs, namely MC159 from Molluscum contagiosum virus and E8 from Equine herpesvirus, were found to also inhibit TNF-induced programmed necrosis (Chan et al. 2003). In contrast to M45, which inhibits necrosis through RHIM-mediated interaction with RIPK3 (Upton et al. 2010), the molecular basis by which vFLIPs inhibit necrosis is not fully understood. Nevertheless, it appears that viral inhibition of necrosis may be a common immune evasion strategy used by many viruses.

\section{NECROSIS IN STERILE INFLAMMATION}

Besides pathogen-induced injury and inflammation, necrosis also plays key roles in sterile injury. It is no surprise that many necrosis-induced sterile injury models involve experimental inhibition of caspases or its upstream adaptor FADD. For instance, retinal detachment induced photoreceptor necrosis in the presence of caspase inhibitor is blocked in RIPK $3^{-/-}$cells 
F.K.-M. Chan

(Trichonas et al.2010). A large number of studies have been performed using caspase $8^{-/-}$or $\mathrm{FADD}^{-/-}$mice. Germline inactivation of these genes results in embryonic lethality that can be rescued by deletion of RIPK1 or RIPK3 (Kaiser et al. 2011; Oberst et al. 2011; Zhang et al. 2011; Dillon et al. 2012). Deletion of these apoptosis mediators in lymphocytes causes defective antigen driven clonal expansion owing to massive necrosis. Again, the defect can be fixed by deletion of RIPK1 or RIPK3 (Ch'en et al. 2011; Lu et al. 2011; Zhang et al.2011). Interestingly, mice deficient in FADD/caspase 8 and RIPK3 developed a lymphoproliferative disease resembling that of lpr mice or the human Autoimmune Lymphoproliferative Syndromes (ALPS), which are caused by mutations in Fas/CD95/APO-1 (Su and Lenardo 2008). Hence, these genetic experiments show that Fas-induced caspase-dependent apoptosis and RIPK1/RIPK3-dependent necrosis coordinately regulate lymphocyte homeostasis to prevent autoimmune lymphoproliferation. Keratinocyte- or intestinal epithelium-specific deletion of results in severe spontaneous inflammation in the respective tissues that can be corrected by deletion of RIPK3 (Kovalenko et al. 2009; Bonnet et al. 2011; Gunther et al. 2011; Welz et al.2011). These results reveal a surprising and unexpected function for FADD and caspase 8: that they are prosurvival factors that suppress the deleterious effects of necrosis, possibly by cleavage and inactivation of RIPK1 and RIPK3.

Sterile necrotic injury can also occur in animals with normal expression of FADD and caspase 8 . Repeated injections of cerulein cause acute pancreatitis marked by loss of acinar cells in the pancreas. RIPK $3^{-/-}$mice are protected from cerulein-induced pancreatitis and acinar cell necrosis (He et al. 2009; Zhang et al. 2009). Myocardial infarction, ischemia induced brain injury, and renal ischemia/reperfusion injury all show hallmarks of necrosis. Administration of the RIPK1 inhibitor necrostatin-1 significantly ameliorates the tissue damage in these injury models (Degterev et al. 2005; Lim et al. 2007; Smith et al. 2007; Northington et al. 2011; Linkermann et al. 2012). Although TNF and other inflammatory cytokines are often elevated in these cases, it is not clear if they are directly responsible for the necrotic cell death. It is plausible that necrosis can ensue without engaging cell surface death receptors in some of these situations. This will be analogous to the "intrinsic" apoptosis induced in response to genotoxic stress.

\section{THERAPEUTIC OPPORTUNITIES}

As discussed in the previous section, necrostatin-1 and its derivatives have shown promise in treating acute injury in several models. This raises the possibility that interfering with necrosis can be an effective strategy to treat certain acute pathologies. Crucially, RIPK $1^{-/-}$mice suffer from postnatal lethality (Kelliher et al. 1998). In addition, RIPK1 has important functions in innate immune signaling (Meylan et al. 2004; Vivarelli et al. 2004) and DNA damage response (Hur et al. 2003; Janssens et al. 2005; Biton and Ashkenazi 2011; Yang et al. 2011). This suggests that long-term use of RIPK1 inhibitors such as necrostatin-1 may be problematic. However, kinases are generally good drug targets and RIPK3-specific inhibitors are attractive therapeutic agents. Several issues need to be taken into account when necrosis is considered as potential therapeutic targets. First, there appears to be a "yin-yang" relationship between apoptosis and necrosis. As we have discussed already, blocking apoptosis often sensitizes cells to necrosis. Inhibiting necrosis appears to have fewer deleterious effects. For example, RIPK $3^{-/-}$ mice are developmentally normal (Newton et al. 2004). However, inhibiting necrosis can exacerbate apoptosis, as recently shown in cFLIP $^{-/-}$RIPK3 $^{-/-}$mice (Dillon et al. 2012). Secondly, RIPK3 has recently been shown to participate in inflammasome activation and inflammatory cytokine production (Vince et al. 2012). Finally, an earlier report shows that RIPK3 was highly induced during cutaneous wound repair (Adams et al. 2007). Thus, RIPK3 inhibitors may impair immune functions and wound healing. Other therapeutic opportunities include targeting downstream effectors such as MLKL. In this light, it will be of great interest to determine the utility of NSA in treating acute and chronic diseases. 


\section{CONCLUDING REMARKS}

We have witnessed a renaissance in necrosis research in the last decade. The discovery of key upstream regulators and demonstration of their functional relevance in development and disease pathologies means that necrosis is no longer an afterthought for biologists. Much is still to be performed to fully understand the biochemical pathway of necrosis. As more investigators join the race to decipher the pathway, one can anticipate with confidence that there will be more exciting discoveries and surprises along the way.

\section{ACKNOWLEDGMENTS}

I thank former and present members of the Chan laboratory and many colleagues for discussion. This work is supported by grants from the NIH (AI083497 and AI088502).

\section{REFERENCES}

Adams S, Pankow S, Werner S, Munz B. 2007. Regulation of NF- $\kappa$ B activity and keratinocyte differentiation by the RIP4 protein: Implications for cutaneous wound repair. J Invest Dermatol 127: 538-544.

Berry DL, Baehrecke EH. 2007. Growth arrest and autophagy are required for salivary gland cell degradation in Drosophila. Cell 131: 1137-1148.

Bertin J, Armstrong RC, Ottilie S, Martin DA, Wang Y, Banks S, Wang GH, Senkevich TG, Alnemri ES, Moss B, et al. 1997. Death effector domain-containing herpesvirus and poxvirus proteins inhibit both Fas- and TNFR1-induced apoptosis. Proc Natl Acad Sci 94: 1172-1176.

Bertrand MJ, Milutinovic S, Dickson KM, Ho WC, Boudreault A, Durkin J, Gillard JW, Jaquith JB, Morris SJ, Barker PA. 2008. cIAP1 and cIAP2 facilitate cancer cell survival by functioning as E3 ligases that promote RIP1 ubiquitination. Mol Cell 30: 689-700.

Biton S, Ashkenazi A. 2011. NEMO and RIP1 control cell fate in response to extensive DNA damage via TNF- $\alpha$ feedforward signaling. Cell 145: 92-103.

Bonnet MC, Preukschat D, Welz PS, van Loo G, Ermolaeva MA, Bloch W, Haase I, Pasparakis M. 2011. The adaptor protein FADD protects epidermal keratinocytes from necroptosis in vivo and prevents skin inflammation. Immunity 35: 572-582.

Brune W, Menard C, Heesemann J, Koszinowski UH. 2001. A ribonucleotide reductase homolog of cytomegalovirus and endothelial cell tropism. Science 291: 303-305.

Carswell EA, Old LJ, Kassel RL, Green S, Fiore N, Williamson B. 1975. An endotoxin-induced serum factor that causes necrosis of tumors. Proc Natl Acad Sci 72: 3666-3670.

Chan FK, Shisler J, Bixby JG, Felices M, Zheng L, Appel M, Orenstein J, Moss B, Lenardo MJ. 2003. A role for tumor necrosis factor receptor-2 and receptor-interacting protein in programmed necrosis and antiviral responses. $J$ Biol Chem 278: 51613-51621.

Ch'en IL, Beisner DR, Degterev A, Lynch C, Yuan J, Hoffmann A, Hedrick SM. 2008. Antigen-mediated T cell expansion regulated by parallel pathways of death. Proc Natl Acad Sci 105: 17463-17468.

Ch'en IL, Tsau JS, Molkentin JD, Komatsu M, Hedrick SM. 2011. Mechanisms of necroptosis in T cells. J Exp Med 208: 633-641.

Cho YS, Challa S, Moquin D, Genga R, Ray TD, Guildford M, Chan FK. 2009. Phosphorylation-driven assembly of the RIP1-RIP3 complex regulates programmed necrosis and virus-induced inflammation. Cell 137: 1112-1123.

Cho Y, McQuade T, Zhang HB, Zhang JK, Chan FKM. 2011. RIP1-dependent and independent effects of necrostatin1 in necrosis and T cell activation. Plos ONE 6.

Degterev A, Huang Z, Boyce M, Li Y, Jagtap P, Mizushima N, Cuny GD, Mitchison TJ, Moskowitz MA, Yuan J. 2005. Chemical inhibitor of nonapoptotic cell death with therapeutic potential for ischemic brain injury. Nat Chem Biol 1: 112-119.

Degterev A, Hitomi J, Germscheid M, Ch'en IL, Korkina O, Teng X, Abbott D, Cuny GD, Yuan C, Wagner G, et al. 2008. Identification of RIP1 kinase as a specific cellular target of necrostatins. Nat Chem Biol 4: 313-321.

Dillon CP, Oberst A, Weinlich R, Janke LJ, Kang TB, BenMoshe T, Mak TW, Wallach D, Green DR. 2012. Survival function of the FADD-CASPASE-8-cFLIPL complex. Cell Rep 1: 401-407.

Ea CK, Deng L, Xia ZP, Pineda G, Chen ZJ. 2006. Activation of IKK by TNF $\alpha$ requires site-specific ubiquitination of RIP1 and polyubiquitin binding by NEMO. Mol Cell 22: 245-257.

Feng S, Yang Y, Mei Y, Ma L, Zhu DE, Hoti N, Castanares M, Wu M. 2007. Cleavage of RIP3 inactivates its caspaseindependent apoptosis pathway by removal of kinase domain. Cell Signal 19: 2056-2067.

Feoktistova M, Geserick P, Kellert B, Dimitrova DP, Langlais C, Hupe M, Cain K, MacFarlane M, Hacker G, Leverkus M. 2011. cIAPs block Ripoptosome formation, a RIP1/caspase-8 containing intracellular cell death complex differentially regulated by cFLIP isoforms. Mol Cell 43: 449-463.

Geserick P, Hupe M, Moulin M, Wong WW, Feoktistova M, Kellert B, Gollnick H, Silke J, Leverkus M. 2009. Cellular IAPs inhibit a cryptic CD95-induced cell death by limiting RIP1 kinase recruitment. J Cell Biol 187: 1037-1054.

Goossens V, De Vos K, Vercammen D, Steemans M, Vancompernolle K, Fiers W, Vandenabeele P, Grooten J. 1999. Redox regulation of TNF signaling. Biofactors 10: 145-156.

Gunther C, Martini E, Wittkopf N, Amann K, Weigmann B, Neumann H, Waldner MJ, Hedrick SM, Tenzer S, Neurath MF, et al. 2011. Caspase- 8 regulates TNF- $\alpha$-induced epithelial necroptosis and terminal ileitis. Nature 477: 335-339. 
F.K.-M. Chan

He S, Wang L, Miao L, Du F, Zhao L, Wang X. 2009. Receptor interacting protein kinase-3 determines cellular necrotic response to TNF- $\alpha$. Cell 137: 1100-1111.

He S, Liang Y, Shao F, Wang X. 2011. Toll-like receptors activate programmed necrosis in macrophages through a receptor-interacting kinase-3-mediated pathway. Proc Natl Acad Sci 108: 20054-20059.

Hitomi J, Christofferson DE, Ng A, Yao J, Degterev A, Xavier RJ, Yuan J. 2008. Identification of a molecula signaling network that regulates a cellular necrotic cell death pathway. Cell 135: 1311-1323.

Hsu H, Huang J, Shu HB, Baichwal V, Goeddel DV. 1996. TNF-dependent recruitment of the protein kinase RIP to the TNF receptor-1 signaling complex. Immunity 4: 387-396.

Hu S, Vincenz C, Buller M, Dixit VM. 1997. A novel family of viral death effector domain-containing molecules that inhibit both CD-95- and tumor necrosis factor receptor1-induced apoptosis. J Biol Chem 272: 9621-9624.

Hur GM, Lewis J, Yang Q, Lin Y, Nakano H, Nedospasov S, Liu ZG. 2003. The death domain kinase RIP has an essential role in DNA damage-induced NF-кB activation. Genes Dev 17: 873-882.

Janssens S, Tinel A, Lippens S, Tschopp J. 2005. PIDD mediates NF- $\mathrm{KB}$ activation in response to DNA damage. Cell 123: $1079-1092$.

Kaiser WJ, Upton JW, Mocarski ES. 2008. Receptor-interacting protein homotypic interaction motif-dependent control of NF- $\mathrm{kB}$ activation via the DNA-dependent activator of IFN regulatory factors. I Immunol 181: 6427-6434.

Kaiser WJ, Upton JW, Long AB, Livingston-Rosanoff D, Daley-Bauer LP, Hakem R, Caspary T, Mocarski ES. 2011. RIP3 mediates the embryonic lethality of caspase-8-deficient mice. Nature 471: 368-372.

Kelliher MA, Grimm S, Ishida Y, Kuo F, Stanger BZ, Leder P. 1998. The death domain kinase RIP mediates the TNFinduced NF-кB signal. Immunity 8: 297-303.

Kim YS, Morgan MJ, Choksi S, Liu ZG. 2007. TNF-induced activation of the Nox1 NADPH oxidase and its role in the induction of necrotic cell death. Mol Cell 26: 675-687.

Kovalenko A, Kim JC, Kang TB, Rajput A, Bogdanov K, Dittrich-Breiholz O, Kracht M, Brenner O, Wallach D. 2009. Caspase-8 deficiency in epidermal keratinocytes triggers an inflammatory skin disease. J Exp Med 206: 2161-2177.

Lembo D, Donalisio M, Hofer A, Cornaglia M, Brune W, Koszinowski U, Thelander L, Landolfo S. 2004. The ribonucleotide reductase $\mathrm{R} 1$ homolog of murine cytomegalovirus is not a functional enzyme subunit but is required for pathogenesis. J Virol 78: 4278-4288.

Li M, Beg AA. 2000. Induction of necrotic-like cell death by tumor necrosis factor $\alpha$ and caspase inhibitors: Novel mechanism for killing virus-infected cells. J Virol 74: 7470-7477.

Li H, Kobayashi M, Blonska M, You Y, Lin X. 2006. Ubiquitination of RIP is required for tumor necrosis factor $\alpha$-induced NF- $\kappa$ B activation. J Biol Chem 281: 1363613643.

Li J, McQuade T, Siemer AB, Napetschnig J, Moriwaki K, Hsiao YS, Damko E, Moquin D, Walz T, McDermott A, et al. 2012. The RIP1/RIP3 necrosome forms a functional amyloid signaling complex required for programmed necrosis. Cell 150: 339-350.

Lim SY, Davidson SM, Mocanu MM, Yellon DM, Smith CC. 2007. The cardioprotective effect of necrostatin requires the cyclophilin-D component of the mitochondrial permeability transition pore. Cardiovasc Drugs Ther 21: 467-469.

Lin Y, Devin A, Rodriguez Y, Liu ZG. 1999. Cleavage of the death domain kinase RIP by caspase- 8 prompts TNFinduced apoptosis. Genes Dev 13: 2514-2526.

Linkermann A, Brasen JH, Himmerkus N, Liu S, Huber TB, Kunzendorf U, Krautwald S. 2012. Rip1 (receptor-interacting protein kinase 1) mediates necroptosis and contributes to renal ischemia/reperfusion injury. Kidney Int 81: 751-761.

Lo SC, Hannink M. 2008. PGAM5 tethers a ternary complex containing Keap1 and Nrf2 to mitochondria. Exp Cell Res 314: $1789-1803$

Lu JV, Weist BM, van Raam BJ, Marro BS, Nguyen LV, Srinivas P, Bell BD, Luhrs KA, Lane TE, Salvesen GS, et al. 2011. Complementary roles of Fas-associated death domain (FADD) and receptor interacting protein kinase3 (RIPK3) in T-cell homeostasis and antiviral immunity. Proc Natl Acad Sci 108: 15312-15317.

Majno G, Joris I. 1995. Apoptosis, oncosis, and necrosis. An overview of cell death. Am J Pathol 146: 3-15.

McComb S, Cheung HH, Korneluk RG, Wang S, Krishnan L, Sad S. 2012. cIAP1 and cIAP2 limit macrophage necroptosis by inhibiting Rip1 and Rip3 activation. Cell Death Differ doi: 10.1038/cdd.2012.59.

Meylan E, Burns K, Hofmann K, Blancheteau V, Martinon F, Kelliher M, Tschopp J. 2004. RIP1 is an essential mediator of Toll-like receptor 3-induced NF-кB activation. Nat Immunol 5: 503-507.

Micheau O, Tschopp J. 2003. Induction of TNF receptor Imediated apoptosis via two sequential signaling complexes. Cell 114: 181-190.

Mocarski ES, Upton JW, Kaiser WJ. 2012. Viral infection and the evolution of caspase 8-regulated apoptotic and necrotic death pathways. Nat Rev Immunol 12: 79-88.

Mollah S, Arnott D, Phung Q, Wertz I, Dixit V, Kayagaki N, Lill J. 2007. Targeted mass spectrometric strategy for global mapping of ubiquitination on proteins. Mol Cell Proteomics 6: $58-58$.

Morgan MJ, Kim YS, Liu ZG. 2009. Membrane-bound Fas ligand requires RIP1 for efficient activation of caspase- 8 within the death-inducing signaling complex. J Immunol 183: $3278-3284$.

Newton K, Sun X, Dixit VM. 2004. Kinase RIP3 is dispensable for normal NF- $\kappa \mathrm{Bs}$, signaling by the B-cell and Tcell receptors, tumor necrosis factor receptor 1 , and Tolllike receptors 2 and 4. Mol Cell Biol 24: 1464-1469.

Newton K, Matsumoto ML, Wertz IE, Kirkpatrick DS, Lill JR, Tan J, Dugger D, Gordon N, Sidhu SS, Fellouse FA, et al. 2008. Ubiquitin chain editing revealed by polyubiquitin linkage-specific antibodies. Cell 134: $668-678$.

Northington FJ, Chavez-Valdez R, Graham EM, Razdan S, Gauda EB, Martin LJ. 2011. Necrostatin decreases 
oxidative damage, inflammation, and injury after neonatal HI. J Cereb Blood Flow Metab 31: 178-189.

Oberst A, Dillon CP, Weinlich R, McCormick LL, Fitzgerald P, Pop C, Hakem R, Salvesen GS, Green DR. 2011. Catalytic activity of the caspase-8-FLIP(L) complex inhibits RIPK3-dependent necrosis. Nature 471: 363367.

O’Donnell MA, Legarda-Addison D, Skountzos P, Yeh WC, Ting AT. 2007. Ubiquitination of RIP1 regulates an NF$\kappa \mathrm{B}$-independent cell-death switch in TNF signaling. Curr Biol 17: 418-424.

O’Donnell MA, Perez-Jimenez E, Oberst A, Ng A, Massoumi R, Xavier R, Green DR, Ting AT. 2011. Caspase 8 inhibits programmed necrosis by processing CYLD. Nat Cell Biol 13: 1437-1442.

Petersen SL, Wang L, Yalcin-Chin A, Li L, Peyton M, Minna J, Harran P, Wang X. 2007. Autocrine TNF $\alpha$ signaling renders human cancer cells susceptible to Smacmimetic-induced apoptosis. Cancer Cell 12: 445-456.

Rebsamen M, Heinz LX, Meylan E, Michallet MC, Schroder K, Hofmann K, Vazquez J, Benedict CA, Tschopp J. 2009. DAI/ZBP1 recruits RIP1 and RIP3 through RIP homotypic interaction motifs to activate NF-кB. EMBO Rep 10: 916-922.

Smith CC, Davidson SM, Lim SY, Simpkin JC, Hothersall JS, Yellon DM. 2007. Necrostatin: A potentially novel cardioprotective agent? Cardiovasc Drugs Ther 21: 227-233.

Stanger BZ, Leder P, Lee TH, Kim E, Seed B. 1995. RIP: A novel protein containing a death domain that interacts with Fas/APO-1 (CD95) in yeast and causes cell death. Cell 81: 513-523.

Su HC, Lenardo MJ. 2008. Genetic defects of apoptosis and primary immunodeficiency. Immunol Allergy Clin North Am 28: 329-351, ix.

Sun L, Wang H, Wang Z, He S, Chen S, Liao D, Wang L, Yan J, Liu W, Lei X, et al. 2012. Mixed lineage kinase domainlike protein mediates necrosis signaling downstream of RIP3 kinase. Cell 148: 213-227.

Takeda K, Komuro Y, Hayakawa T, Oguchi H, Ishida Y, Murakami S, Noguchi T, Kinoshita H, Sekine Y, Iemura S, et al. 2009. Mitochondrial phosphoglycerate mutase 5 uses alternate catalytic activity as a protein serine/threonine phosphatase to activate ASK1. Proc Natl Acad Sci 106: 12301-12305.

Tenev T, Bianchi K, Darding M, Broemer M, Langlais C, Wallberg F, Zachariou A, Lopez J, MacFarlane M, Cain K, et al. 2011. The Ripoptosome, a signaling platform that assembles in response to genotoxic stress and loss of IAPs. Mol Cell 43: 432-448.

Thome M, Schneider P, Hofmann K, Fickenscher H, Meinl E, Neipel F, Mattmann C, Burns K, Bodmer JL, Schroter M, et al. 1997. Viral FLICE-inhibitory proteins (FLIPs) prevent apoptosis induced by death receptors. Nature 386: 517-521.

Ting AT, Pimentel-Muinos FX, Seed B. 1996. RIP mediates tumor necrosis factor receptor 1 activation of NF- $\kappa B$ but not Fas/APO-1-initiated apoptosis. EMBO J 15: 6189-6196.

Trichonas G, Murakami Y, Thanos A, Morizane Y, Kayama M, Debouck CM, Hisatomi T, Miller JW, Vavvas DG. 2010. Receptor interacting protein kinases mediate retinal detachment-induced photoreceptor ne- crosis and compensate for inhibition of apoptosis. Proc Natl Acad Sci 107: 21695-21700.

Tu HC, Ren D, Wang GX, Chen DY, Westergard TD, Kim H, Sasagawa S, Hsieh JJ, Cheng EH. 2009. The p53-cathepsin axis cooperates with ROS to activate programmed necrotic death upon DNA damage. Proc Natl Acad Sci 106: $1093-1098$

Upton JW, Kaiser WJ, Mocarski ES. 2008. Cytomegalovirus M45 cell death suppression requires receptor-interacting protein (RIP) homotypic interaction motif (RHIM)-dependent interaction with RIP1. J Biol Chem 283: 16966-16970.

Upton JW, Kaiser WJ, Mocarski ES. 2010. Virus inhibition of RIP3-dependent necrosis. Cell Host Microbe 7: 302-313.

Upton JW, Kaiser WJ, Mocarski ES. 2012. DAI/ZBP1/ DLM-1 complexes with RIP3 to mediate virus-induced programmed necrosis that is targeted by murine cytomegalovirus vIRA. Cell Host Microbe 11: 290-297.

Vandenabeele P, Galluzzi L, Vanden Berghe T, Kroemer G. 2010. Molecular mechanisms of necroptosis: an ordered cellular explosion. Nat Rev Mol Cell Biol 11: 700-714.

Vanden Berghe T, Vanlangenakker N, Parthoens E, Deckers W, Devos M, Festjens N, Guerin CJ, Brunk UT, Declercq W, Vandenabeele P. 2010. Necroptosis, necrosis and secondary necrosis converge on similar cellular disintegration features. Cell Death Differ 17: 922-930.

Vanlangenakker N, Vanden Berghe T, Bogaert P, Laukens B, Zobel K, Deshayes K, Vucic D, Fulda S, Vandenabeele P, Bertrand MJ. 2011. cIAP1 and TAK1 protect cells from TNF-induced necrosis by preventing RIP1/RIP3-dependent reactive oxygen species production. Cell Death Differ 18: $656-665$.

Varfolomeev E, Blankenship JW, Wayson SM, Fedorova AV, Kayagaki N, Garg P, Zobel K, Dynek JN, Elliott LO, Wallweber HJ, et al. 2007. IAP antagonists induce autoubiquitination of c-IAPs, NF- $\mathrm{BB}$ activation, and TNF $\alpha$ dependent apoptosis. Cell 131: 669-681.

Vercammen D, Beyaert R, Denecker G, Goossens V, Van Loo G, Declercq W, Grooten J, Fiers W, Vandenabeele P 1998. Inhibition of caspases increases the sensitivity of L929 cells to necrosis mediated by tumor necrosis factor. $J$ Exp Med 187: 1477-1485.

Vince JE, Wong WW, Khan N, Feltham R, Chau D, Ahmed AU, Benetatos CA, Chunduru SK, Condon SM, McKinlay M, et al. 2007. IAP antagonists target cIAP1 to induce TNF $\alpha$-dependent apoptosis. Cell 131: 682-693.

Vince JE, Wong WW, Gentle I, Lawlor KE, Allam R, O'Reilly L, Mason K, Gross O, Ma S, Guarda G, et al. 2012. Inhibitor of apoptosis proteins limit RIP3 kinasedependent interleukin-1 activation. Immunity 36: 215227.

Vivarelli MS, McDonald D, Miller M, Cusson N, Kelliher M, Geha RS. 2004. RIP links TLR4 to Akt and is essential for cell survival in response to LPS stimulation. J Exp Med 200: 399-404.

von Recklinghausen F. 1910. Untersuchungen über rachitis und osteomalazie. Verlag Gustav Fischer Jena, Stuttgart.

Wang L, Du F, Wang X. 2008. TNF- $\alpha$ induces two distinct caspase-8 activation pathways. Cell 133: 693-703. 
F.K.-M. Chan

Wang Z, Jiang H, Chen S, Du F, Wang X. 2012. The mitochondrial phosphatase PGAM5 functions at the convergence point of multiple necrotic death pathways. Cell 148: 228-243.

Welz PS, Wullaert A, Vlantis K, Kondylis V, FernandezMajada V, Ermolaeva M, Kirsch P, Sterner-Kock A, van Loo G, Pasparakis M. 2011. FADD prevents RIP3-mediated epithelial cell necrosis and chronic intestinal inflammation. Nature 477: 330-334.

Wong WW, Gentle IE, Nachbur U, Anderton H, Vaux DL, Silke J. 2010. RIPK1 is not essential for TNFR1-induced activation of NF-кB. Cell Death Differ 17: 482-487.

Xu M, Skaug B, Zeng W, Chen ZJ. 2009. A ubiquitin replacement strategy in human cells reveals distinct mechanisms of IKK activation by TNF $\alpha$ and IL-1 $\beta$. Mol Cell 36: 302-314.

Yang Y, Xia F, Hermance N, Mabb A, Simonson S, Morrissey S, Gandhi P, Munson M, Miyamoto S, Kelliher MA. 2011. A cytosolic ATM/NEMO/RIP1 complex recruits TAK1 to mediate the NF- $\mathrm{KB}$ and $\mathrm{p} 38$ mitogen-activated protein kinase (MAPK)/MAPK-activated protein 2 responses to DNA damage. Mol Cell Biol 31: 2774-2786.
Yazdanpanah B, Wiegmann K, Tchikov V, Krut O, Pongratz C, Schramm M, Kleinridders A, Wunderlich T, Kashkar H, Utermohlen O, et al. 2009. Riboflavin kinase couples TNF receptor 1 to NADPH oxidase. Nature 460: 1159-1163.

Yu L, Alva A, Su H, Dutt P, Freundt E, Welsh S, Baehrecke EH, Lenardo MJ. 2004. Regulation of an ATG7beclin 1 program of autophagic cell death by caspase-8. Science 304: 1500-1502.

Zhang DW, Shao J, Lin J, Zhang N, Lu BJ, Lin SC, Dong MQ, Han J. 2009. RIP3, an energy metabolism regulator that switches TNF-induced cell death from apoptosis to necrosis. Science 325: 332-336.

Zhang H, Zhou X, McQuade T, Li J, Chan FK, Zhang J. 2011. Functional complementation between FADD and RIP1 in embryos and lymphocytes. Nature 471: 373-376.

Zhao J, Jitkaew S, Cai Z, Choksi S, Li Q, Luo J, Liu ZG. 2012. Mixed lineage kinase domain-like is a key receptor interacting protein 3 downstream component of TNF-induced necrosis. Proc Natl Acad Sci 109: 5322-5327.

Zhou Q, Snipas S, Orth K, Muzio M, Dixit VM, Salvesen GS. 1997. Target protease specificity of the viral serpin CrmA Analysis of five caspases. J Biol Chem 272: 7797-7800. 


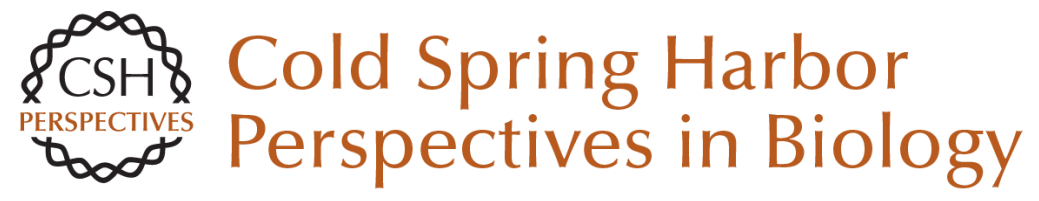

\section{Fueling the Flames: Mammalian Programmed Necrosis in Inflammatory Diseases}

Francis Ka-Ming Chan

Cold Spring Harb Perspect Biol 2012; doi: 10.1101/cshperspect.a008805

Subject Collection Cell Survival and Cell Death

Programmed Cell Death in the Evolutionary Race against Bacterial Virulence Factors

Carolyn A. Lacey and Edward A. Miao

The Evolutionary Origins of Programmed Cell

Death Signaling

Kay Hofmann

Regulation of Cell Death and Immunity by XIAP Philipp J. Jost and Domagoj Vucic

Dysregulation of Cell Death in Human Chronic Inflammation

Yue Li, Christoph Klein and Daniel Kotlarz

Cell Death in Plant Immunity

Eugenia Pitsili, Ujjal J. Phukan and Nuria S. Coll

Recent Insights on Inflammasomes, Gasdermin

Pores, and Pyroptosis

Nathalia M. de Vasconcelos and Mohamed Lamkanfi

Phagocyte Responses to Cell Death in Flies Andrew J. Davidson and Will Wood

Mechanism and Regulation of Gasdermin-Mediated Cell Death

Shiyu Xia, Louis Robert Hollingsworth IV and Hao
Cell Death and Neurodegeneration

Benjamin J. Andreone, Martin Larhammar and Joseph W. Lewcock

Death Receptors and Their Ligands in

Inflammatory Disease and Cancer Alessandro Annibaldi and Henning Walczak

The Killer Pseudokinase Mixed Lineage Kinase Domain-Like Protein (MLKL) James M. Murphy

Neutrophil Extracellular Traps in Host Defense Sabrina Sofia Burgener and Kate Schroder

Cell-Cycle Cross Talk with Caspases and Their

Substrates

Patrick Connolly, Irmina Garcia-Carpio and Andreas Villunger

Cracking the Cell Death Code

Carla V. Rothlin and Sourav Ghosh

BAX, BAK, and BOK: A Coming of Age for the BCL-2 Family Effector Proteins

Tudor Moldoveanu and Peter E. Czabotar

Multitasking Kinase RIPK1 Regulates Cell Death and Inflammation

Kim Newton

For additional articles in this collection, see http://cshperspectives.cshlp.org/cgi/collection/

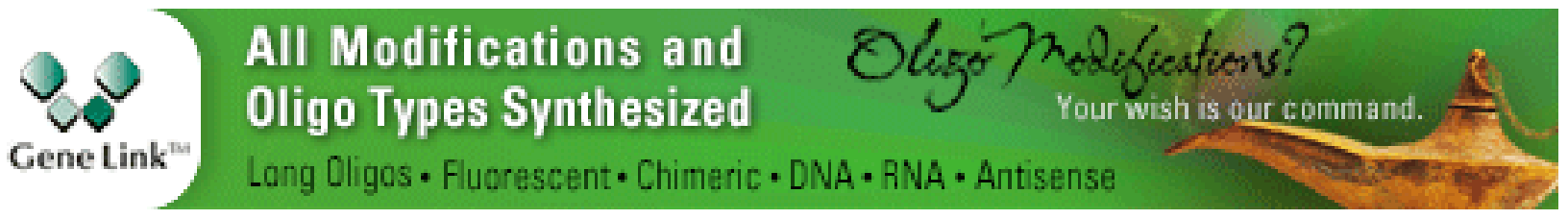

Copyright (C 2012 Cold Spring Harbor Laboratory Press; all rights reserved 
For additional articles in this collection, see http://cshperspectives.cshlp.org/cgi/collection/

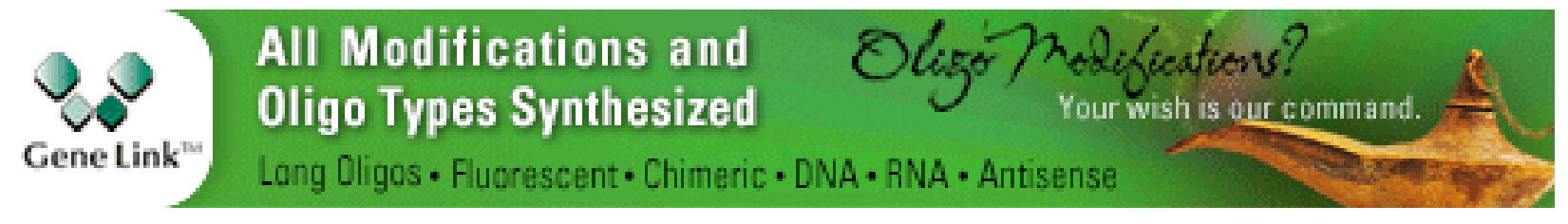

Copyright @ 2012 Cold Spring Harbor Laboratory Press; all rights reserved 